\title{
Imposex in Two Muricid Species (Mollusca: Gastropoda) from the Northeastern Brazilian Coast
}

\author{
I. B. Castro,,${ }^{1,2 *}$ A. F. Alves de Lima, ${ }^{2}$ A. R. C. Braga ${ }^{1} \&$ C. A. Rocha-Barreira ${ }^{1}$ \\ 'Divisão de Oceanografia Biológica, Instituto de Ciências Marinha, LABOMAR/UFC, \\ Av. da Abolição, 3207, Bairro Meireles, CEP 60165-081, Fortaleza, CE, Brasil \\ ${ }^{2}$ Fundação Universidade Federal do Rio Grande, C.P. 474, CEP 96201-900, Rio Grande, RS, Brasil \\ (Received October 7, 2006; Accepted January 17, 2007)
}

\begin{abstract}
Imposex is the occurrence of male sexual features in female prosobranch mollusks exposed to organotin compounds. Since imposex has measurable characteristics, it has been used as a bioindication tool for the presence of this kind of pollutants. Thus, this work aimed to monitor organotin pollution over areas under the influence of ten main harbors of Northeastern Brazilian coast. Imposex intensity was measured using the indexes VDSI, RPSI, RPLI and the percentage of imposexed females. At least one sampling site in each studied harbor showed imposex, suggesting a widespread contamination by organotin compounds. However, the observed imposex levels are lower than those obtained by other monitoring works in highly industrialized regions of Europe and Asia, confirming that organotin contamination levels are higher in the most industrialized regions of the world. Approximately 39\% of all sampling sites (32 sites) did not show imposexed females, suggesting that this feature does not occur naturally in Stramonita haemastoma and Stramonita rustica.
\end{abstract}

Key words: Gastropoda, harbor, imposex, muricidae, organotin compounds, Stramonita haemastoma, Stramonita rustica.

\section{RESUMO}

\section{Imposex em duas espécies de muricídeos (Mollusca: Gastropoda) da costa do Nordeste do Brasil}

O imposex é a ocorrência de caracteres sexuais masculinos em fêmeas de moluscos prosobrânquios expostos a compostos orgânicos de estanho (COEs). Como o imposex apresenta características mensuráveis, o mesmo tem sido usado como bioindicador de baixo custo para esse tipo de poluição. O presente trabalho monitorou a contaminação por compostos organoestânicos nas áreas sob a influência dos 10 principais terminais portuários do Nordeste do Brasil. A intensidade de imposex foi medida utilizando-se os índices VDSI, RPSI e RPLI e a porcentagem de fêmeas com imposex. Pelo menos uma estação em cada um dos terminais portuários estudados apresentou imposex, sugerindo ampla contaminação por COEs. Entretanto, os índices observados revelaram-se baixos quando comparados aos obtidos em outros monitoramentos realizados em regiões muito industrializadas da Europa e da Ásia. Isso reforça dados já mencionados na literatura que sugerem que a contaminação por compostos orgânicos de estanho é mais severa em regiões mais industrializadas do mundo. Das 82 estações analisadas durante o presente estudo, 32 mostraram-se completamente livres de quaisquer indícios de imposex, o que sugere que o imposex não se manifesta naturalmente nas espécies Stramonita haemastoma e Stramonita rustica.

Palavras-chave: Gastropoda, porto, imposex, muricidae, compostos organoestânicos, Stramonita haemastoma, Stramonita rustica.

*Corresponding author: Ítalo Braga Castro, e-mail: italo_braga@yahoo.com.br. 


\section{INTRODUCTION}

Imposex in gastropod mollusks has been widely used to monitor contamination by organotin compounds all over the world (Morcillo \& Porte, 1998; Axiak et al., 2002; Minchin, 2003). The reliability of this bioindicator lays on the fact that imposex is caused by a specific hormonal alteration, occurring only in gastropods exposed to organotin compounds (Matthiessen \& Gibbs, 1998). Although imposex has already been observed in Latin America (Gooding et al., 1999; Penchaszadeh et al., 2001), no comprehensive monitoring studies have been so far conducted in this region.

In Brazil, imposex was observed in the muricids Stramonita haemastoma (Lanneus, 1767) (Castro et al., 2000; Fernandez et al., 2002; Fernandez et al., 2005; Castro et al., 2007), Stramonita rustica (Lamarck, 1822) (Camillo et al., 2004; Castro et al., 2004), and in the olivid Olivancillaria vesica (Gmelin, 1791) (Caetano \& Absalão, 2003).

There are more than 130 different mollusk species known that have shown imposex and 38 of them belonging to the Muricidae family (Castro et al., in press). Muricidae is probably the most widely mollusk taxon used as a bioindicator for the contamination by organotin compounds all over the world.

Thus, this study aimed to verify the occurrence of imposex in muricid gastropod populations from the 10 main harbors of Northeastern Brazilian coast.

\section{MATERIALS AND METHODS}

\section{Study area and sampling}

The 10 studied harbors of the Northeastern Brazilian coast were: Pecém and Mucuripe (State of Ceará); Natal (State of Rio Grande do Norte); Cabedelo (State of Paraíba); Recife and Suape (State of Pernambuco); Jaraguá (State of Alagoas); Aracaju (State of Sergipe) and Salvador and Aratu (State of Bahia).

A total of 82 sites were sampled throughout the area under the influence of each of the 10 monitored harbors (Table 1). The sampling points were chosen considering the distance from the harbor, availability of muricid gastropods and direction of the predominant local currents. Thirty adult muricids of either Stramonita haemastoma (Harbors of Pecém, Mucuripe and Cabedelo) or Stramonita rustica (Harbor of Natal, Recife, Jaraguá, Aracaju, Salvador and Aratu) (approximately $30 \mathrm{~mm}$ long) were sampled from each site (whenever possible) between February and November 2004.

\section{Laboratory proceedings}

The animals were sedated with a $3.5 \% \mathrm{MgCl}_{2}$ solution for 2 hours. Their shells were then measured from the tip of the spiral to the siphon channel using vernier calliper. The shell of each individual was then removed in order to examine the soft tissues. Sexual identification was performed based on the presence of a seminal receptacle in the females, and a prostate gland in males.

The imposex levels in each site were quantified using the following indexes: \% of imposex in females; Relative Penis Length Index (RPLI), calculated by the equation (mean penis length in females/mean penis length in males) $\times 100$ (Gibbs $\&$ Bryan, 1987); Relative Penis Size Index (RPSI), calculated by the equation (mean penis length in females) ${ }^{3} /$ (mean penis length in males) ${ }^{3} \times 100$ (Gibbs \& Bryan, 1987); and Vas Deferens Sequence Index (VDSI). VDSI was based on the sixstage scale proposed by Gibbs \& Bryan (1987) for the species Nucella lapillus and adapted by Fernandez et al. (2005) for Stramonita haemastoma. Such option was chosen because of the difficult visualization of the vas deferens in the muricids of the Stramonita genus.

\section{RESULTS AND DISCUSSION}

The highest imposex indexes at Pecém harbor (State of Ceará) were found at the harbor jetty (S2), decreasing with the distance from the harbor up to São Pedro beach (S5), which showed no evidences of imposex (Figure 1). The observed gradient of imposex indexes in the Pecém harbor area followed the east-west direction of the predominant coastal currents (Maia, 1998). However, some evidences of imposex were again observed further away at São Pedro ou Paracuru beach (S6) and Point of Paracuru (S7), probably due to the traffic of vessels towards the pier of Petrobras (oil exploration company), which is located at this beach.

The values obtained at the Pecém harbor (State of Ceará) were not as high as other areas monitored with S. haemastoma, which can be explained by the short existence of this harbor (operations started in 2002) and relatively low traffic $(<500$ ships between 2002 and 2004) (CEP, 2004). A similar situation was observed in a marina in Thailand where the initial levels of imposex were low but increased with time (Bech, 2002).

At the Mucuripe harbor (State of Ceará), the highest levels were found at Mansa Beach (S9 - RPLI = 76.0), decreasing with distance the harbor. Sites located eastwards showed much lower evidences of imposex due to probably the predominant coastal currents. Previously, Castro et al. (2000) showed that the western limit of imposex was at Dois Coqueiros beach (S3). However, the present study found imposex further away at Pacheco beach (S1), indicating an expansion of the area contaminated by organotin compounds, which might be related to an increase in the Ceará River flow just before the sampling dates, because of a very intense rainy season, and a shipyard located at the river mouth, where repairs of small ships are performed. 
Table 1 - Description of the sampling sites and specie used for monitoring (number of organisms).

\begin{tabular}{|c|c|c|c|c|c|}
\hline Harbor & Site & Description & Latitude & Longitude & Specie used(n) \\
\hline \multirow{7}{*}{$\begin{array}{c}\text { Pecém } \\
\text { (Ceará State) }\end{array}$} & S1 & Cauípe Beach & $3^{\circ} 34^{\prime} 38^{\prime \prime}$ & $38^{\circ} 47^{\prime} 10^{\prime \prime}$ & S. haemastoma (30) \\
\hline & $\mathrm{S} 2$ & Jetty of Harbor & $3^{\circ} 32^{\prime} 40^{\prime \prime}$ & $38^{\circ} 48^{\prime} 34^{\prime \prime}$ & S. haemastoma (30) \\
\hline & S3 & Pecém Beach & $3^{\circ} 32^{\prime} 48^{\prime \prime}$ & $38^{\circ} 49^{\prime} 50^{\prime \prime}$ & S. haemastoma (30) \\
\hline & S4 & Taíba Beach & $3^{\circ} 31^{\prime} 69^{\prime \prime}$ & $38^{\circ} 52^{\prime} 37^{\prime \prime}$ & S. haemastoma (30) \\
\hline & S5 & São Pedro Beach & $3^{\circ} 24^{\prime} 34^{\prime \prime}$ & $38^{\circ} 58^{\prime} 31^{\prime \prime}$ & S. haemastoma (30) \\
\hline & S6 & Paracuru Beach & $3^{\circ} 23^{\prime} 60^{\prime \prime}$ & $38^{\circ} 00^{\prime} 49^{\prime \prime}$ & S. haemastoma (30) \\
\hline & S7 & Point of Paracuru & $3^{\circ} 24^{\prime} 13^{\prime \prime}$ & $39^{\circ} 01 ’ 25^{\prime \prime}$ & S. haemastoma (30) \\
\hline \multirow{12}{*}{$\begin{array}{c}\text { Mucuripe } \\
\text { (Ceará State) }\end{array}$} & $\mathrm{S} 1$ & Pacheco Beach & $3^{\circ} 41^{\prime} 09^{\prime \prime}$ & $38^{\circ} 37^{\prime} 45^{\prime \prime}$ & S. haemastoma (30) \\
\hline & $\mathrm{S} 2$ & Iparana Beach & $3^{\circ} 41^{\prime} 13^{\prime \prime}$ & $38^{\circ} 37^{\prime} 03^{\prime \prime}$ & S. haemastoma (30) \\
\hline & $\mathrm{S} 3$ & Dois Coqueiros Beach & $3^{\circ} 41^{\prime} 21^{\prime \prime}$ & $38^{\circ} 36^{\prime} 45^{\prime \prime}$ & S. haemastoma (30) \\
\hline & S4 & Barra Beach & $3^{\circ} 41^{\prime} 54^{\prime \prime}$ & $38^{\circ} 35^{\prime} 15^{\prime \prime}$ & S. haemastoma (30) \\
\hline & S5 & Formosa Beach & $3^{\circ} 42^{\prime} 53^{\prime \prime}$ & $38^{\circ} 32^{\prime} 40^{\prime \prime}$ & S. haemastoma (30) \\
\hline & S6 & Poço da Draga Beach & $3^{\circ} 43^{\prime} 06^{\prime \prime}$ & $38^{\circ} 31^{\prime} 02^{\prime \prime}$ & S. haemastoma (30) \\
\hline & S7 & Ideal Beach & $3^{\circ} 35^{\prime} 56^{\prime \prime}$ & $38^{\circ} 30^{\prime} 07^{\prime \prime}$ & S. haemastoma (30) \\
\hline & S8 & Meireles Beach & $3^{\circ} 28^{\prime} 29^{\prime \prime}$ & $38^{\circ} 28^{\prime} 30^{\prime \prime}$ & S. haemastoma (28) \\
\hline & S9 & Mansa Beach & $3^{\circ} 42^{\prime} 12^{\prime \prime}$ & $38^{\circ} 28^{\prime} 34^{\prime \prime}$ & S. haemastoma (30) \\
\hline & $\mathrm{S} 10$ & Titã Beach & $3^{\circ} 42^{\prime} 28^{\prime \prime}$ & $38^{\circ} 28^{\prime} 02^{\prime \prime}$ & S. haemastoma (30) \\
\hline & S11 & Caça e Pesca Beach & $3^{\circ} 45^{\prime} 54^{\prime \prime}$ & $38^{\circ} 26^{\prime} 18^{\prime \prime}$ & S. haemastoma (30) \\
\hline & $\mathrm{S} 12$ & Sabiaguaba Beach & $3^{\circ} 46^{\prime} 27^{\prime \prime}$ & $38^{\circ} 25^{\prime} 54^{\prime \prime}$ & S. haemastoma (30) \\
\hline \multirow{9}{*}{$\begin{array}{c}\text { Natal } \\
\text { (Rio Grande do Norte } \\
\text { State) }\end{array}$} & $\mathrm{S} 1$ & Barreira D'Água Beach & $5^{\circ} 47^{\prime} 70^{\prime \prime}$ & $35^{\circ} 10^{\prime} 92^{\prime \prime}$ & S. rustica (30) \\
\hline & S2 & Ponta do Morcego Beach & $5^{\circ} 47^{\prime} 13^{\prime \prime}$ & $35^{\circ} 11^{\prime} 38^{\prime \prime}$ & S. rustica (23) \\
\hline & S3 & Meio Beach & $5^{\circ} 46^{\prime} 49^{\prime \prime}$ & $35^{\circ} 11^{\prime} 44^{\prime \prime}$ & S. rustica (30) \\
\hline & S4 & Forte Beach & $5^{\circ} 45^{\prime} 46^{\prime \prime}$ & $35^{\circ} 11^{\prime} 68^{\prime \prime}$ & S. rustica (30) \\
\hline & S5 & Potengi River estuary (int) & $5^{\circ} 46^{\prime} 01^{\prime \prime}$ & $35^{\circ} 12^{\prime} 18^{\prime \prime}$ & S. rustica (30) \\
\hline & S6 & Potengi River estuary (ext) & $5^{\circ} 46^{\prime} 01^{\prime \prime}$ & $35^{\circ} 12^{\prime} 19^{\prime \prime}$ & S. rustica (18) \\
\hline & S7 & Harbor - ferryboat & $5^{\circ} 46^{\prime} 00^{\prime \prime}$ & $35^{\circ} 28^{\prime} 22^{\prime \prime}$ & S. rustica (30) \\
\hline & S8 & Jetty of Redinha & $5^{\circ} 45^{\prime} 14^{\prime \prime}$ & $35^{\circ} 12^{\prime} 08^{\prime \prime}$ & S. rustica (30) \\
\hline & S9 & Santa Rita Beach & $5^{\circ} 42^{\prime} 15^{\prime \prime}$ & $35^{\circ} 11^{\prime} 53^{\prime \prime}$ & S. rustica (30) \\
\hline \multirow{9}{*}{$\begin{array}{c}\text { Cabedelo } \\
\text { (Paraíba State) }\end{array}$} & $\mathrm{S} 1$ & Harbor & $6^{\circ} 58^{\prime} 40^{\prime \prime}$ & $34^{\circ} 50^{\prime} 00^{\prime \prime}$ & S. haemastoma (30) \\
\hline & $\mathrm{S} 2$ & Jetty of Paraíba & $6^{\circ} 57^{\prime} 45^{\prime \prime}$ & $34^{\circ} 50^{\prime} 35^{\prime \prime}$ & S. haemastoma (30) \\
\hline & $\mathrm{S} 3$ & Ponta do Mato Beach & $6^{\circ} 57^{\prime} 59^{\prime \prime}$ & $34^{\circ} 49^{\prime} 47^{\prime \prime}$ & S. haemastoma (30) \\
\hline & S4 & Formosa Beach & $6^{\circ} 58^{\prime} 43^{\prime \prime}$ & $34^{\circ} 49^{\prime} 40^{\prime \prime}$ & S. haemastoma (30) \\
\hline & S5 & Areia Dourada Beach & $6^{\circ} 57^{\prime} 40^{\prime \prime}$ & $34^{\circ} 49^{\prime} 31^{\prime \prime}$ & S. haemastoma (30) \\
\hline & S6 & Camboinha Beach & $6^{\circ} 58^{\prime} 56^{\prime \prime}$ & $34^{\circ} 49^{\prime} 12^{\prime \prime}$ & S. haemastoma (30) \\
\hline & $\mathrm{S} 7$ & Intermares Beach & $6^{\circ} 59^{\prime} 31^{\prime \prime}$ & $34^{\circ} 48^{\prime} 55^{\prime \prime}$ & S. haemastoma (30) \\
\hline & S8 & Costinha Beach & $6^{\circ} 57^{\prime} 40^{\prime \prime}$ & $34^{\circ} 49^{\prime} 31^{\prime \prime}$ & S. haemastoma (30) \\
\hline & S9 & Lucena Beach & $6^{\circ} 57^{\prime} 40^{\prime \prime}$ & $34^{\circ} 49^{\prime} 01^{\prime \prime}$ & S. haemastoma (19) \\
\hline
\end{tabular}


Table 1 - (Continuação).

\begin{tabular}{|c|c|c|c|c|c|}
\hline Harbor & Site & Description & Latitude & Longitude & Specie used(n) \\
\hline \multirow{7}{*}{$\begin{array}{c}\text { Recife } \\
\text { (Pernambuco State) }\end{array}$} & S1 & Boa Viagem Beach & $8^{\circ} 07^{\prime} 12^{\prime \prime}$ & $34^{\circ} 03^{\prime} 22^{\prime \prime}$ & S. rustica (30) \\
\hline & S2 & Boa Viagem Beach & $8^{\circ} 06^{\prime} 25^{\prime \prime}$ & $34^{\circ} 53^{\prime} 04^{\prime \prime}$ & S. rustica (30) \\
\hline & S3 & Pina Beach & $8^{\circ} 05^{\prime} 37^{\prime \prime}$ & $34^{\circ} 2^{\prime} 52^{\prime \prime}$ & S. rustica (30) \\
\hline & S4 & Brasília Teimosa Beach & $8^{\circ} 04^{\prime} 46^{\prime \prime}$ & $34^{\circ} 52^{\prime} 34^{\prime \prime}$ & S. rustica (30) \\
\hline & S5 & Jetty of Harbor & $8^{\circ} 03^{\prime} 49^{\prime \prime}$ & $34^{\circ} 51^{\prime} 03^{\prime \prime}$ & S. rustica (30) \\
\hline & S6 & Milagres Beach & $8^{\circ} 03^{\prime} 01^{\prime \prime}$ & $34^{\circ} 51^{\prime} 12^{\prime \prime}$ & S. rustica (30) \\
\hline & S7 & Bairro Novo Beach & $8^{\circ} 02^{\prime} 42^{\prime \prime}$ & $34^{\circ} 51^{\prime} 23^{\prime \prime}$ & S. rustica (30) \\
\hline \multirow{7}{*}{$\begin{array}{c}\text { Suape } \\
\text { (Pernambuco State) }\end{array}$} & $\mathrm{S} 1$ & Portode Galinhas Beach & $8^{\circ} 23^{\prime} 43^{\prime \prime}$ & $34^{\circ} 55^{\prime} 57^{\prime \prime}$ & S. rustica (30) \\
\hline & S2 & Muro Alto Beach & $8^{\circ} 22^{\prime} 06^{\prime \prime}$ & $34^{\circ} 56^{\prime} 37^{\prime \prime}$ & S. rustica (30) \\
\hline & S3 & Suape Beach & $8^{\circ} 21^{\prime} 54^{\prime \prime}$ & $34^{\circ} 56^{\prime} 49^{\prime \prime}$ & S. rustica (30) \\
\hline & $\mathrm{S} 4$ & Point of $\mathrm{St}^{\mathrm{o}}$ Agostinho & $8^{\circ} 21 ' 20^{\prime \prime}$ & $34^{\circ} 56^{\prime} 60^{\prime \prime}$ & S. rustica (30) \\
\hline & S5 & Guaibú Beach & $8^{\circ} 20^{\prime} 14^{\prime \prime}$ & $34^{\circ} 57^{\prime} 02^{\prime \prime}$ & S. rustica (30) \\
\hline & S6 & Inlet of Coral & $8^{\circ} 19^{\prime} 33^{\prime \prime}$ & $34^{\circ} 56^{\prime} 59^{\prime \prime}$ & S. rustica (30) \\
\hline & S7 & Pedra do Xaréu Beach & $8^{\circ} 18^{\prime} 59^{\prime \prime}$ & $34^{\circ} 56^{\prime} 54^{\prime \prime}$ & S. rustica (30) \\
\hline \multirow{10}{*}{$\begin{array}{c}\text { Jaraguá } \\
\text { (Alagoas State) }\end{array}$} & $\mathrm{S} 1$ & Sereia Beach & $9^{\circ} 34^{\prime} 00^{\prime \prime}$ & $35^{\circ} 38^{\prime} 45^{\prime \prime}$ & S. rustica (30) \\
\hline & $\mathrm{S} 2$ & Cruz das Almas Beach & $9^{\circ} 37^{\prime} 31^{\prime \prime}$ & $35^{\circ} 41 ’ 37^{\prime \prime}$ & S. rustica (30) \\
\hline & S3 & Yacht Club & $9^{\circ} 39^{\prime} 53^{\prime \prime}$ & $35^{\circ} 41^{\prime} 46^{\prime \prime}$ & S. rustica (30) \\
\hline & S4 & Eastern Jetty Harbor & $9^{\circ} 40^{\prime} 41^{\prime \prime}$ & $35^{\circ} 43^{\prime} 11^{\prime \prime}$ & S. rustica $(30)$ \\
\hline & S5 & Western Jetty Harbor & $9^{\circ} 40^{\prime} 25^{\prime \prime}$ & $35^{\circ} 43^{\prime} 27^{\prime \prime}$ & S. rustica (30) \\
\hline & S6 & Emissary & $9^{\circ} 40^{\prime} 32^{\prime \prime}$ & $35^{\circ} 45^{\prime} 10^{\prime \prime}$ & S. rustica (30) \\
\hline & S7 & Terminal & $9^{\circ} 41^{\prime} 10^{،} ،$ & $35^{\circ} 45^{\prime} 51^{\prime \prime}$ & S. rustica (30) \\
\hline & S8 & Sacoda Pedra Beach & $9^{\circ} 44^{\prime} 53^{\prime \prime}$ & $35^{\circ} 49^{\prime} 22^{\prime \prime}$ & S. rustica $(30)$ \\
\hline & S9 & Francês Beach & $9^{\circ} 46^{\prime} 00^{\prime \prime}$ & $35^{\circ} 50^{\prime} 14^{\prime \prime}$ & S. rustica (30) \\
\hline & $\mathrm{S} 10$ & São Miguel Beach & $9^{\circ} 50^{\prime} 42^{\prime \prime}$ & $35^{\circ} 54^{\prime} 23^{\prime \prime}$ & S. rustica (30) \\
\hline \multirow{7}{*}{$\begin{array}{c}\text { Aracaju } \\
\text { (Sergipe river estuary - } \\
\text { Sergipe State) }\end{array}$} & S1 & Aracaju Terminal & $10^{\circ} 54^{\prime} 37^{\prime \prime}$ & $37^{\circ} 02^{\prime} 52^{\prime \prime}$ & S. rustica (30) \\
\hline & S2 & Barra dos Coqueiros Beach & $10^{\circ} 54^{\prime} 27^{\prime \prime}$ & $37^{\circ} 02^{\prime} 22^{\prime \prime}$ & S. rustica (30) \\
\hline & S3 & Yacht Club & $10^{\circ} 55^{\prime} 27^{\prime \prime}$ & $37^{\circ} 02^{\prime} 36^{\prime \prime}$ & S. rustica (30) \\
\hline & S4 & Atalaia Nova Terminal & $10^{\circ} 56^{\prime} 25^{\prime \prime}$ & $37^{\circ} 02^{\prime} 06^{\prime \prime}$ & S. rustica (30) \\
\hline & S5 & Jetty of Atalaia Nova & $10^{\circ} 56^{\prime} 59^{\prime \prime}$ & $37^{\circ} 01^{\prime} 57^{\prime \prime}$ & S. rustica $(30)$ \\
\hline & S6 & Jetty of Coroa do Meio & $10^{\circ} 57^{\prime} 12^{\prime \prime}$ & $37^{\circ} 01^{\prime} 22^{\prime \prime}$ & S. rustica $(30)$ \\
\hline & S7 & Jetty of Praia do Farol & $10^{\circ} 58^{\prime} 26^{\prime \prime}$ & $37^{\circ} 01^{\prime} 03^{\prime \prime}$ & S. rustica (25) \\
\hline \multirow{14}{*}{$\begin{array}{c}\text { Salvador e Aratu } \\
\text { (Todos os Santos Bay - } \\
\text { Bahia State) }\end{array}$} & $\mathrm{S} 1$ & Bom Despacho Beach & $13^{\circ} 01 ' 35^{\prime \prime}$ & $38^{\circ} 40^{\prime} 59^{\prime \prime}$ & S. rustica (30) \\
\hline & $\mathrm{S} 2$ & Mar Grande Beach & $13^{\circ} 01^{\prime} 67^{\prime \prime}$ & $38^{\circ} 41^{\prime} 24^{\prime \prime}$ & S. rustica (30) \\
\hline & S3 & Barra Grande Beach & $13^{\circ} 02^{\prime} 25^{\prime \prime}$ & $38^{\circ} 40^{\prime} 33^{\prime \prime}$ & S. rustica (30) \\
\hline & S4 & Acapulco Beach & $13^{\circ} 03^{\prime} 27^{\prime \prime}$ & $38^{\circ} 42^{\prime} 14^{\prime \prime}$ & S. rustica (13) \\
\hline & S5 & Aratuba Beach & $13^{\circ} 05^{\prime} 22^{\prime \prime}$ & $38^{\circ} 44^{\prime} 30^{\prime \prime}$ & S. rustica (30) \\
\hline & S6 & Rio Vermelho Beach & $13^{\circ} 00^{\prime} 53^{\prime \prime}$ & $38^{\circ} 29^{\prime} 19^{\prime \prime}$ & S. rustica (30) \\
\hline & S7 & Ondina Beach & $13^{\circ} 00^{\prime} 40^{\prime \prime}$ & $38^{\circ} 30^{\prime} 32^{\prime \prime}$ & S. rustica $(30)$ \\
\hline & S8 & Farol da Barra Beach & $13^{\circ} 00^{\prime} 40^{\prime \prime}$ & $38^{\circ} 31^{\prime} 54^{\prime \prime}$ & S. rustica (30) \\
\hline & S9 & Yatch Clube & $12^{\circ} 59^{\prime} 54^{\prime \prime}$ & $38^{\circ} 31^{\prime} 47^{\prime \prime}$ & S. rustica (30) \\
\hline & S10 & Harbor Authority & $12^{\circ} 58^{\prime} 30^{\prime \prime}$ & $38^{\circ} 30^{\prime} 60^{\prime \prime}$ & S. rustica (30) \\
\hline & S11 & Canta Galo Beach & $12^{\circ} 56^{\prime} 16^{\prime \prime}$ & $38^{\circ} 30^{\prime} 25^{\prime \prime}$ & S. rustica (30) \\
\hline & $\mathrm{S} 12$ & Ribeira Beach & $12^{\circ} 55^{\prime} 21^{\prime \prime}$ & $38^{\circ} 30^{\prime} 06^{\prime \prime}$ & S. rustica (30) \\
\hline & $\mathrm{S} 13$ & Maré Island & $12^{\circ} 47^{\prime} 54^{\prime \prime}$ & $38^{\circ} 31^{\prime} 34^{\prime \prime}$ & S. rustica (30) \\
\hline & $\mathrm{S} 14$ & Aratu Bay & $12^{\circ} 48^{\prime} 36^{\prime \prime}$ & $38^{\circ} 30^{\prime} 01^{\prime \prime}$ & S. rustica (30) \\
\hline
\end{tabular}




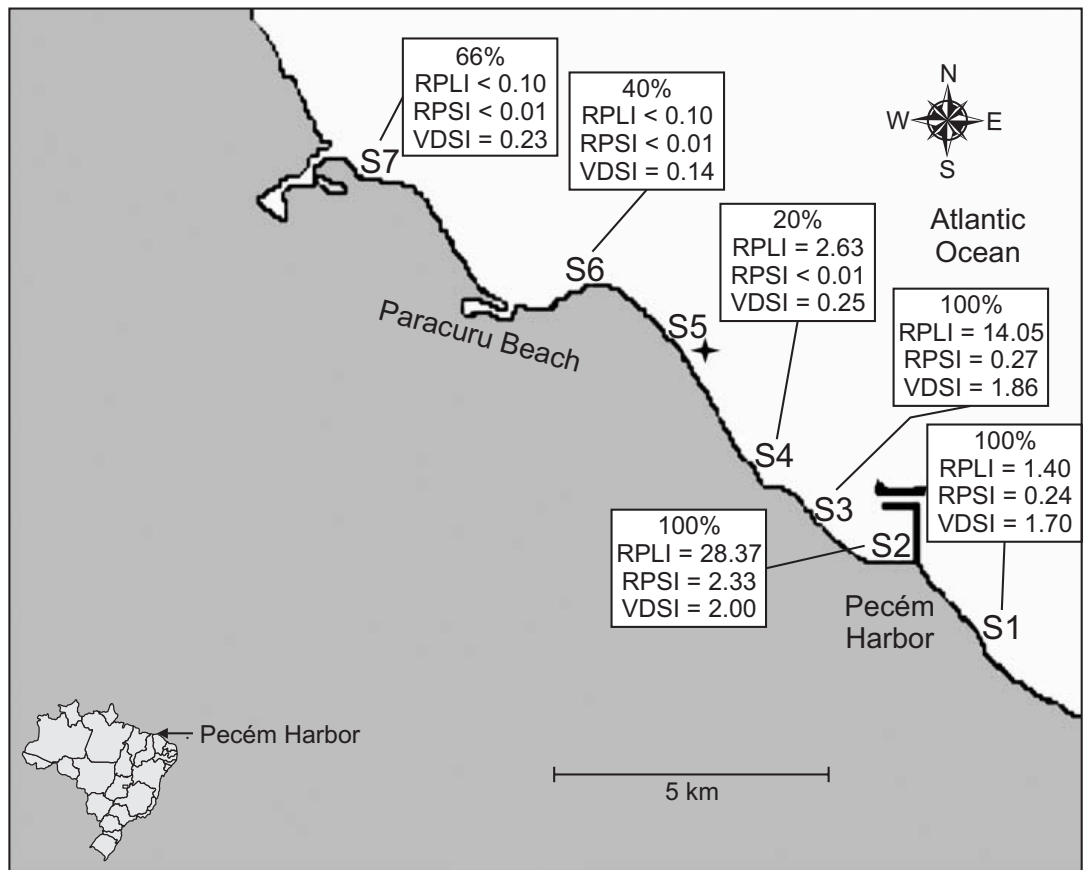

Figure 1 - Imposex frequency (\%), RPLI, RPSI and VDSI for each site sampled nearby the Pecém harbor and adjacent coastal area in Ceará State. (†) Imposex not observed.

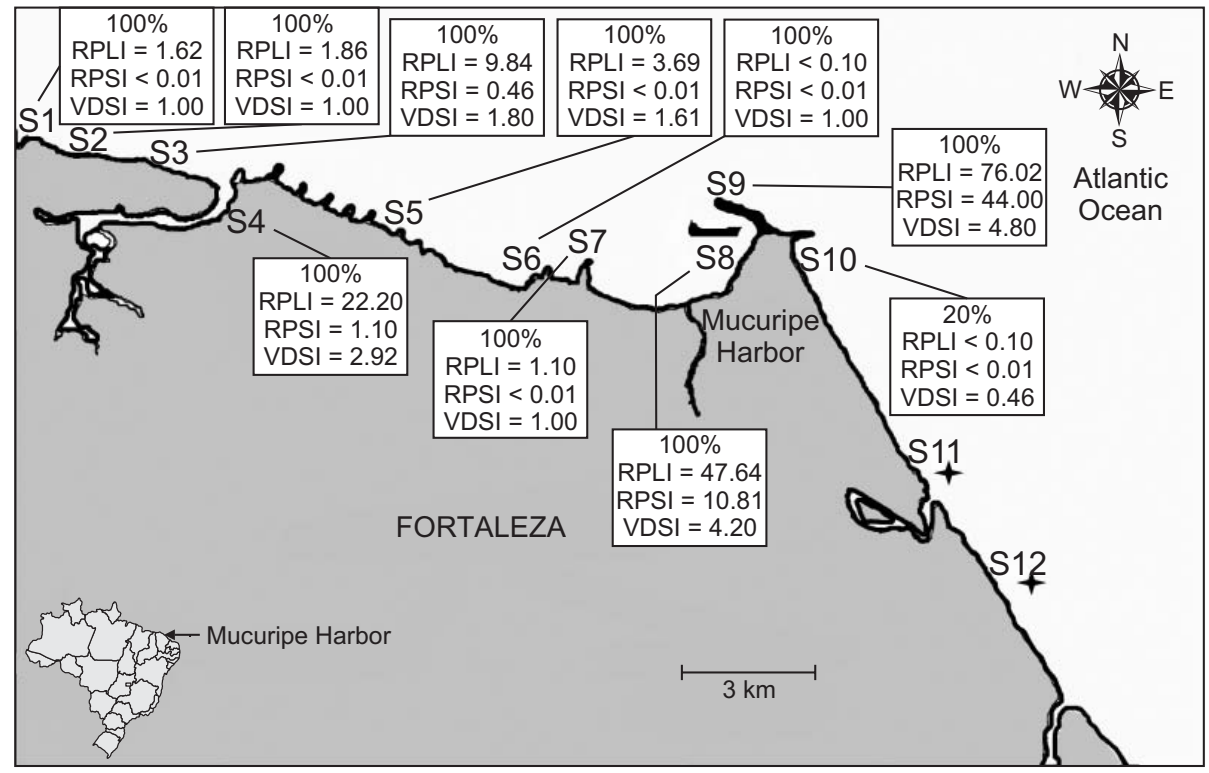

Figure 2 - Imposex frequency (\%), RPLI, RPSI and VDSI for each site sampled nearby the Mucuripe harbor and adjacent coastal area in Ceará State. ( + ) Imposex not observed. 
The highest levels of imposex at Natal harbor (State of Rio Grande do Norte) were found at the Harbor (S7 - RPLI = 32.3) and Potengi River mouth (S5 and S8), decreased with distance from the possible sources. Three sites showed no evidence of imposex (Figure 3). In a previous study, Castro et al. (2004) showed high levels of imposex up to Praia do Forte (S4). Although the present work indicated a slight decrease in imposex levels, the imposex-stricken area was still wide (up to Meio beach (S3)). The currents dominating the coast of Natal flow in the south to north direction (Castro et al., 2003), which may explain the low imposex values obtained in the outer face of the harbor jetty (S6).

The observed imposex indexes at Cabedelo harbor (State of Paraíba) were moderate compared to other harbors in the northeast of Brazil. The highest indexes were found nearby the harbor at both banks of the Paraíba do Norte River (S1 - RPLI = 22.1 and S8 = RPLI = 13.4). Indexes decreased with distance from the harbor, showing no evidence of imposex at Formosa beach (S4), Areia Dourada (S5), Intermares beach (S6) and Lucena beach (S9) (Figure 4). This can be attributable to the comparatively low traffic of the Cabedelo harbor (MTB, 2004).

Four out of seven sites nearby the Harbor of Recife (State of Pernambuco) showed no imposex, while the highest levels were found in the outer face of the harbor jetty (site S5), decreasing with the distance from the harbor (Figure 5). Since the Harbor of Suape construction, Recife has been reducing the number of ship operations (MTB, 2004). In addition, the study sites were located outside the harbor jetty, an area with strong hydrodynamics. These may help to explain the low imposex levels registered in the region.

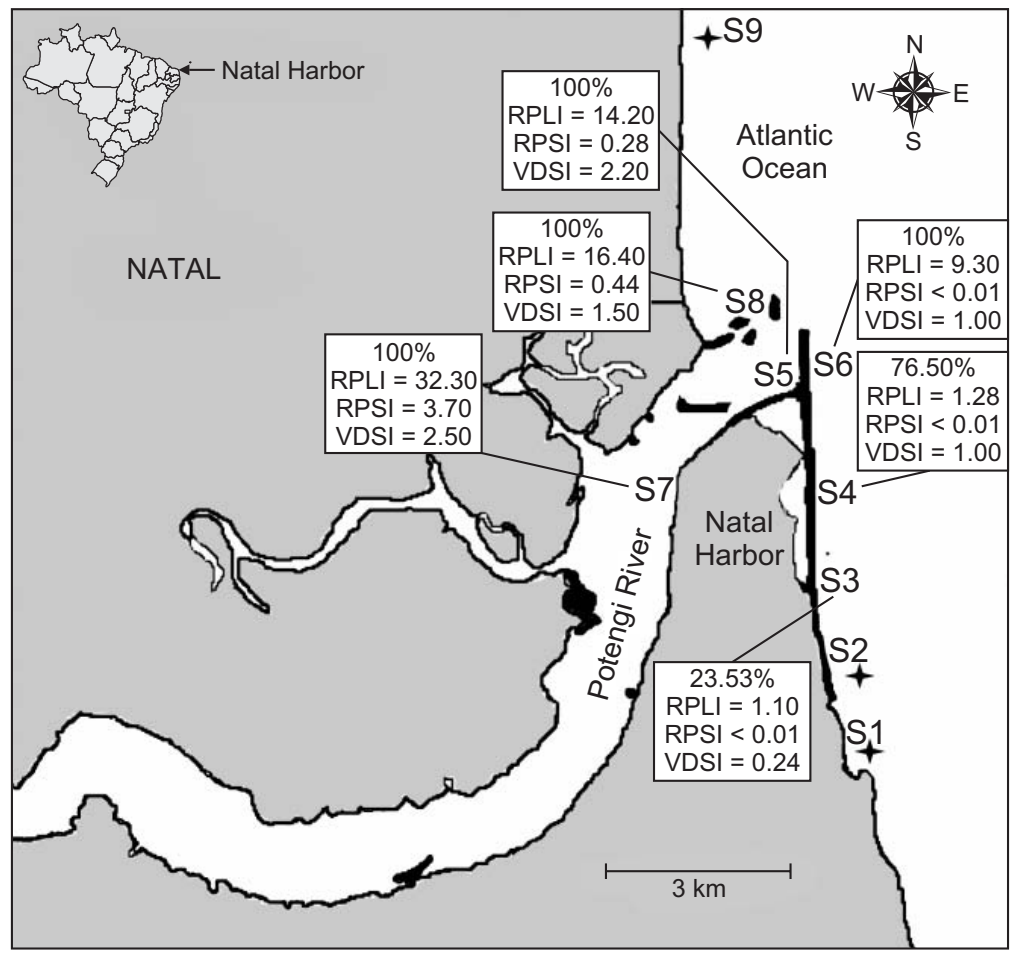

Figure 3 - Imposex frequency (\%), RPLI, RPSI and VDSI for each site sampled nearby the Natal harbor and adjacent coastal area in Rio Grande do Norte State. (†) Imposex not observed. 


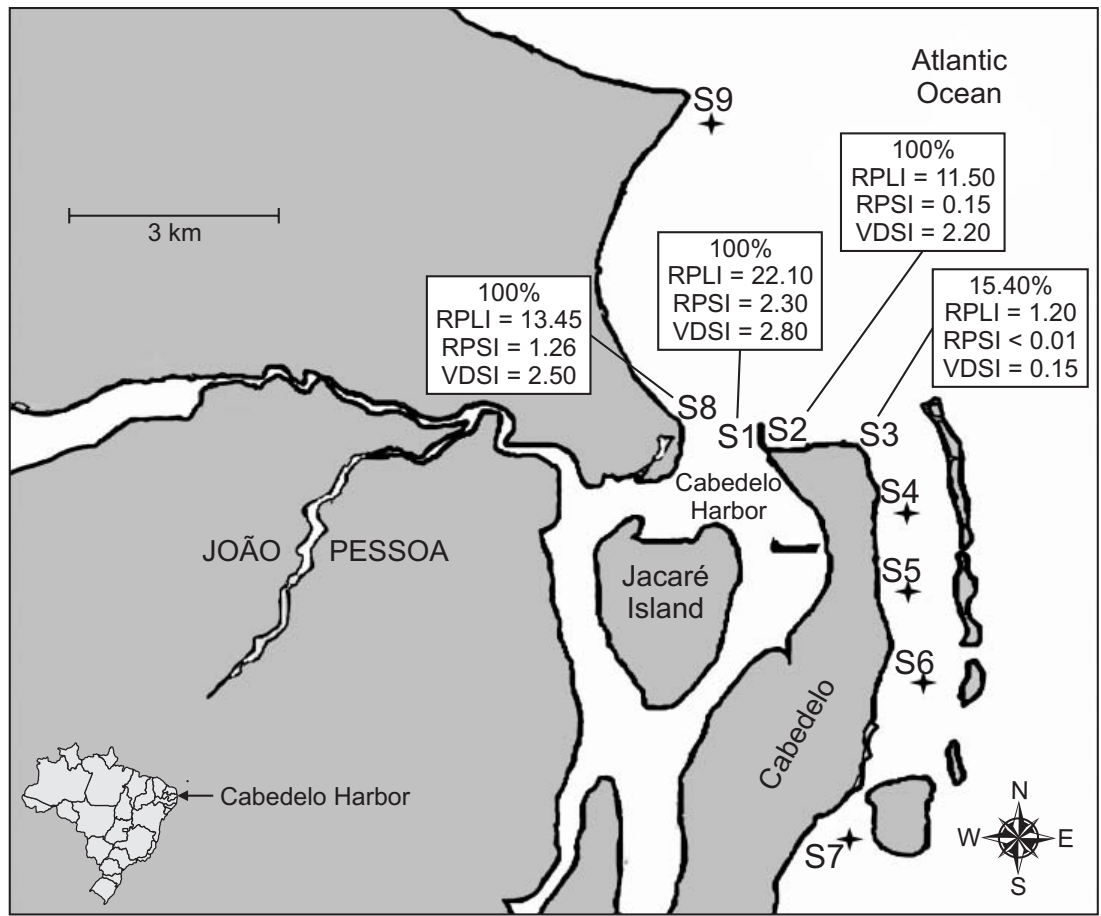

Figure 4 - Imposex frequency (\%), RPLI, RPSI and VDSI for each site sampled nearby the Cabedelo harbor and adjacent coastal area in Paraíba State. (†) Imposex not observed.

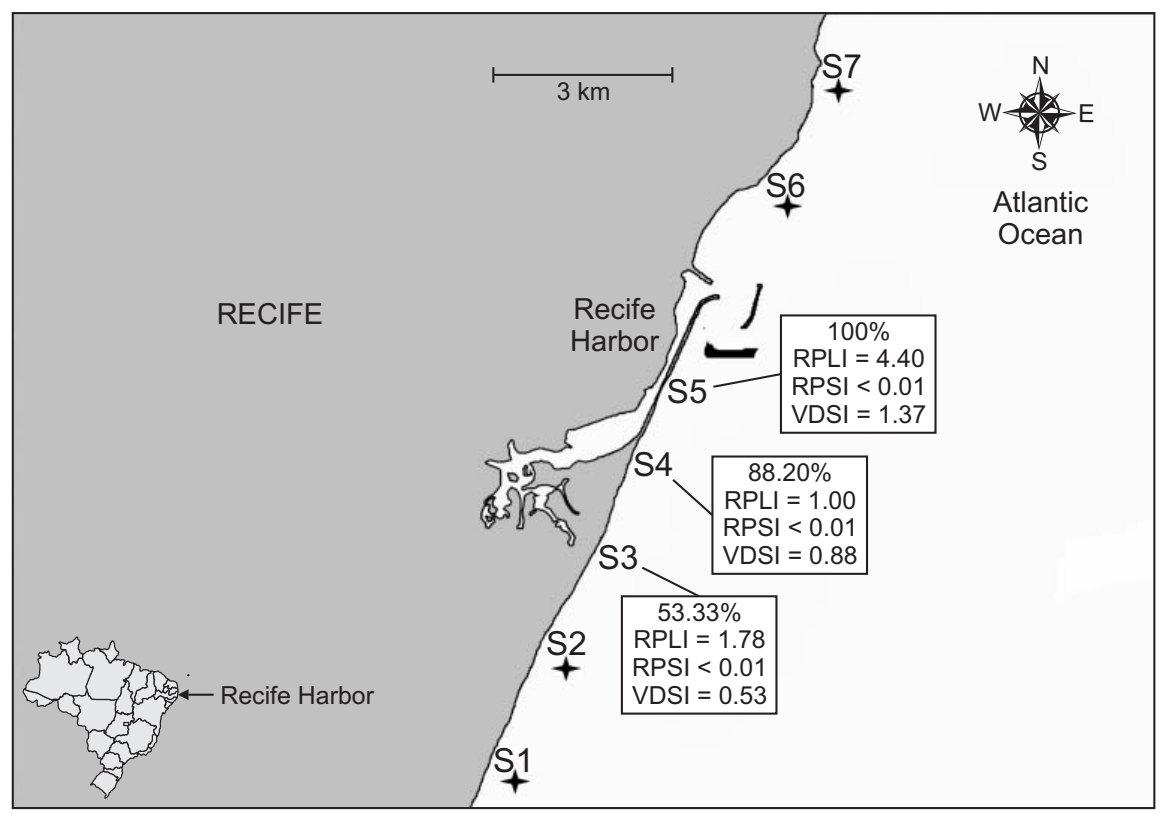

Figure 5 - Imposex frequency (\%), RPLI, RPSI and VDSI for each site sampled nearby the Recife harbor and adjacent coastal area in Pernambuco State. ( + ) Imposex not observed. 
A very low level of imposex was found in just one of the seven monitored sites of Suape harbor (State of Pernambuco) (Figure 6). The low imposex levels found around the Suape harbor are probably caused by several factors, such as the recent beginning of its operations (MTB, 2004), the local hydrodynamics and its "off-shore" location, which allows a better dilution of the pollutants released by the vessels.

At the Jaraguá harbor (State of Alagoas), the highest imposex indexes were found in the southwestern side of the harbor, at the Western Jetty Harbor (S5 - RPLI = 36.1 and VDSI of up to IV). Levels gradually decreased towards the southwest, while sites towards the northeast showed no imposex at all (Figure 7). Site S5 showed the highest imposex levels among all monitored harbors from the northeastern Brazilian coast using $S$. rustica. These values were higher than those recorded by Camillo et al. (2004) for the site S5 (RPLI = 33.1). More detailed studies have to be performed to find out if these increasing levels are related to an increase in the number of vessels at the harbor.

In Aracaju (State of Sergipe) the monitoring was performed at the Sergipe river estuary, which has an intense traffic of small vessels. The highest levels of imposex were found at the Terminal of Barra dos Coqueiros beach (S2 - RPLI $=50.27$ and VSDI up to III), decreasing with distance. No imposex was found in the Coroa do Meio beach (S6) and Farol beach (S7) (Figure 8). Such high imposex levels at site S2 suggest that, despite the region does not have an intense traffic of vessels, the organotin compounds released into the waters by small ships may accumulate in the sediments, due to the degree of protection of this area, thus having a longer residence time in the local waters.

Five out of fourteen monitored sites in the Todos os Santos Bay (including Salvador and Aratu harbors - State of Bahia) showed no evidences of imposex. The highest levels were found at the Salvador harbor $(\mathrm{S} 10-\mathrm{RPLI}=14.8$ and VDSI $=1.5)$ (Figure 9). Despite some areas around the Todos os Santos Bay are between the most urbanized and industrialized of the Brazilian Northeast and with intense traffic of vessels, the imposex levels were lower than those found by this study in other locations. However, the width of the channel communicating the bay with the Atlantic ocean, as well as its significant depth, may contribute to the dilution of pollutants within the bay, decreasing their impact to biota.

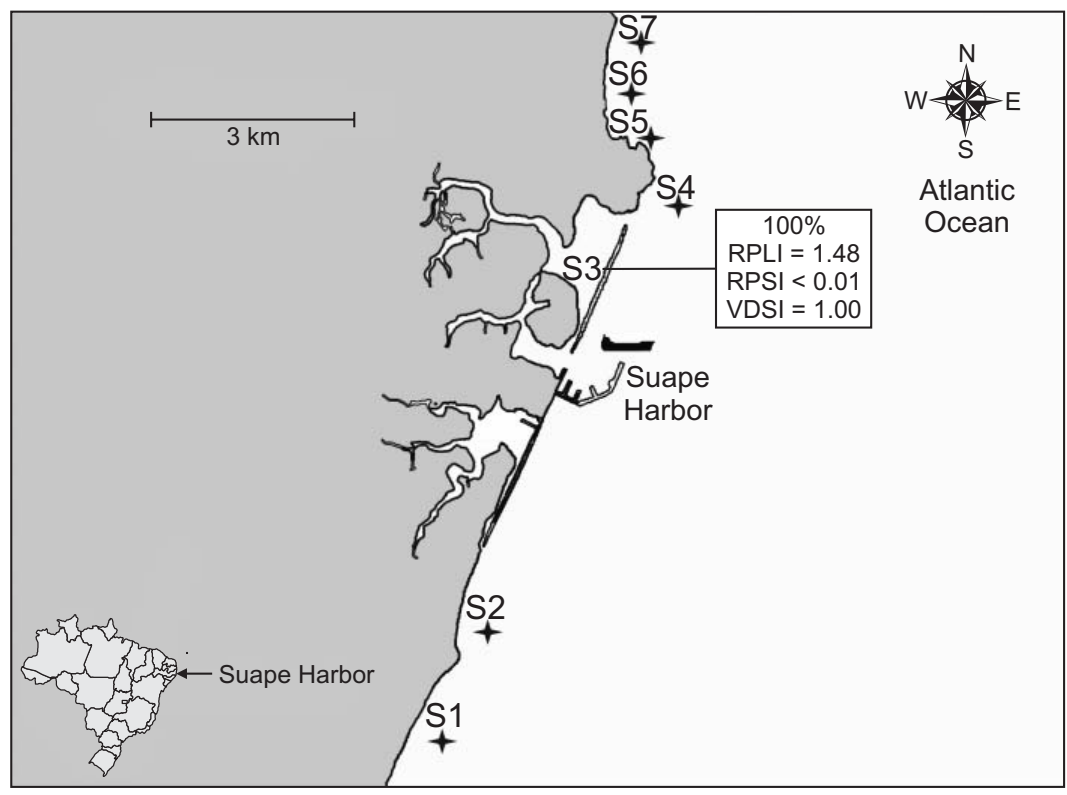

Figure 6 - Imposex frequency (\%), RPLI, RPSI and VDSI for each site sampled nearby the Suape harbor and adjacent coastal area in Pernambuco State. ( + ) Imposex not observed. 


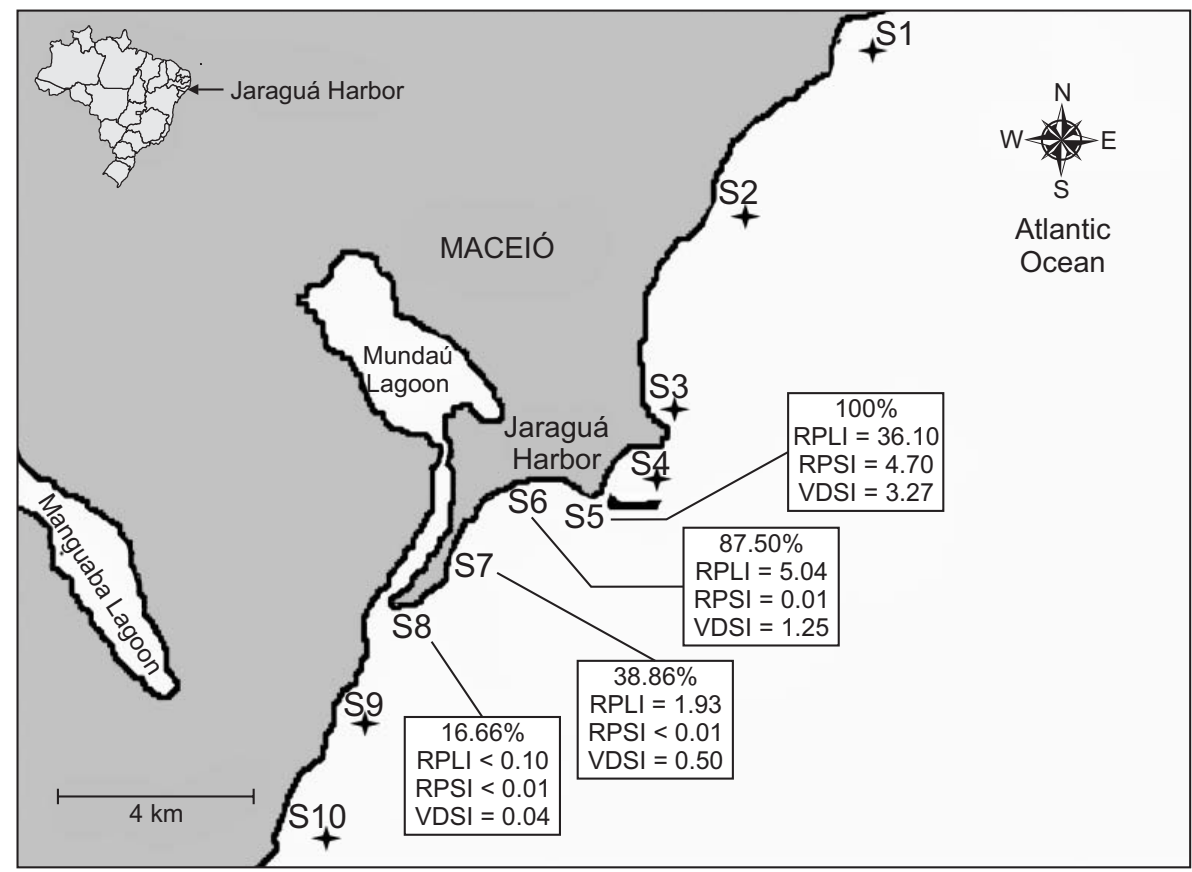

Figure 7 - Imposex frequency (\%), RPLI, RPSI and VDSI for each site sampled nearby the Jaraguá harbor and adjacent coastal area in Alagoas State. ( + Imposex not observed.

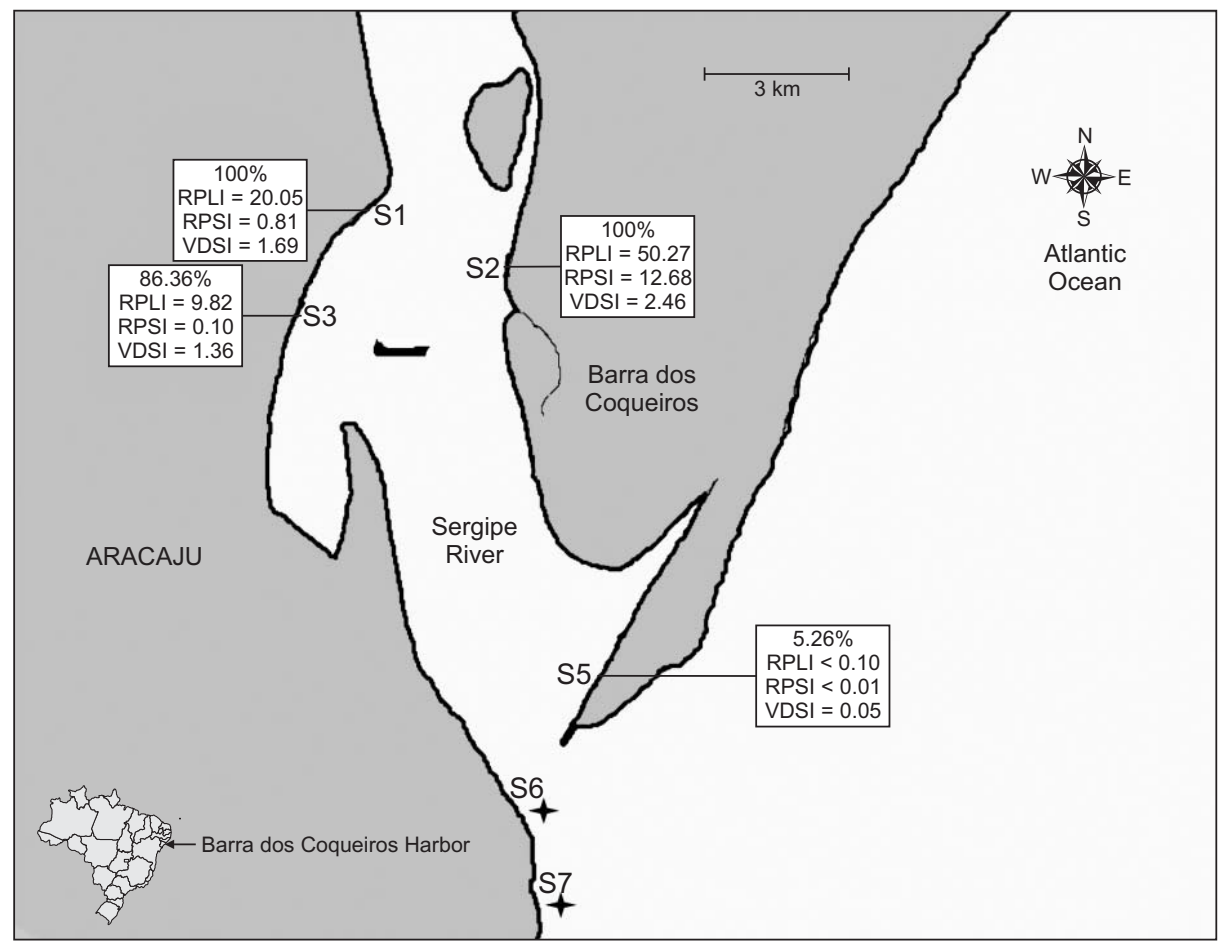

Figure 8 - Imposex frequency (\%), RPLI, RPSI and VDSI for site sampled at Sergipe river estuary area in Sergipe State. (†) Imposex not observed. 
This study showed the occurrence of imposex in all monitored areas. A gradient was found in most areas, i.e. decreasing imposex indexes as the sites were more distant from the harbors. In addition, other parameters such as water depth, local hydrodynamics and availability of monitoring species must be taken into account (ten Hallers-Tjabbes et al., 2003). Similar results were observed in studies performed in the Mediterranean, using Hexaplex trunculus (Linnaeus, 1758) (Axiak et al., 1995), in Crok Harbor, Ireland, using Nucella lapillus (Linnaeus, 1758) and Littorina littorea (Linnaeus, 1758) (Minchin et al., 1996), in Phuket Island, Thailand, using Chicoreus capucinus (Lamarck, 1822) and Thais distinguenda (Roding, 1798) (Bech, 2002), in Fishing Port, Kyllibegs, Ireland, using Nucella lapillus and Littorina littorea (Minchin \& Minchin, 1997), and at many other locations.

In most harbors where $S$. rustica was used as bioindicator, the imposex indexes were lower, confirming that $S$. rustica is less sensitive to organotin contamination than S. haemastoma (Castro et al., unpublished results).

Imposex is an hormone regulation failure, which can be triggered by a very low concentrations $\left(\mathrm{ng} \mathrm{L}^{-1}\right)$ of organotin compounds in most prosobranchiate mollusks (Mensink et al., 1997; Morcillo \& Porte, 1998). Thus, very industrialized coastal area which receive a large number of vessels are expected to show higher imposex indexes as a result of higher contamination by organotin compounds. A study done in Japan with Thais clavigera (Dunker, 1860) and T. bronni (Dunker, 1860) showed all sites with $100 \%$ imposex and most of the RPSI values higher than 40 (Horiguchi et al., 1997). The imposex indexes observed in the studied sites were lower than those found in bigger harbors from Brazil, such as Guanabara Bay, RJ (Fernandez et al., 2005), and around the world. However, it is important to carry out chemical analysis to get the real extension of organotin contamination in those areas where imposex was observed.

Studies performed with the species Hexaplex trunculus (Axiak et al., 2002) and Nucella lapillus (Davies et al., 1997) reported the occurrence of natural imposex levels in populations not exposed to organotin compounds. However, it is suggested that this feature does not occur naturally in Stramonita haemastoma and Stramonita rustica, since 32 out of 82 sampled sites showed no signs of imposex, especially those far away from possible organotin sources.

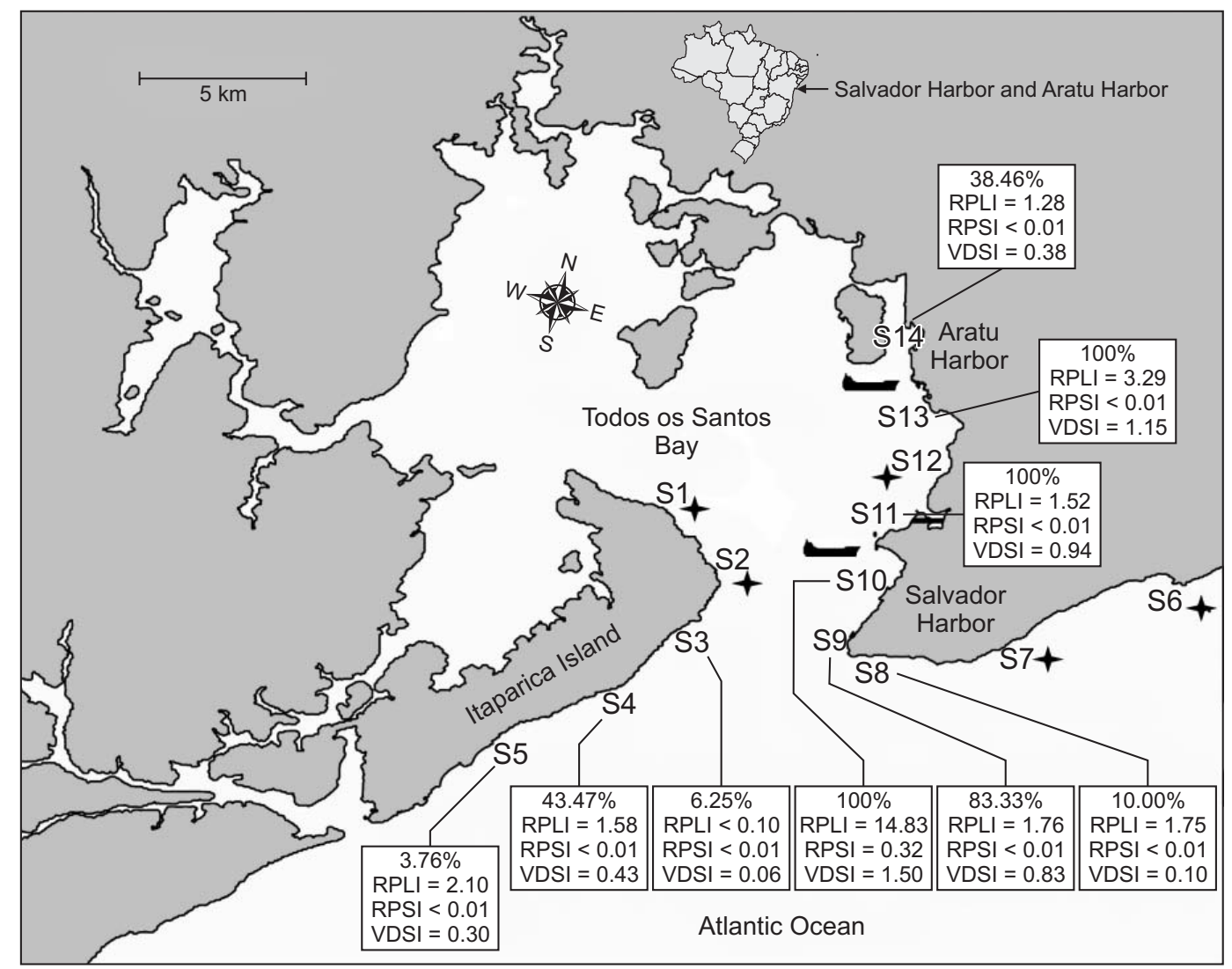

Figure 9 - Imposex frequency (\%), RPLI and VDSI for site sampled at Todos os Santos Bay in Bahia State. (†) Imposex not observed. 


\section{CONCLUSIONS}

The occurrence of imposex in all ten monitored harbors of Northeastern Brazilian coast suggests that sudied areas have different degrees of organotin contamination. Thus, chemical analysis are necessary to avaluate the real extension of contamination.

S. rustica showed to be less sensitive to organotin contamination than $S$. haemastoma, but imposex does not seem to occur naturally in these especies, since a significant part of the individuals sampled in areas far away from possible organotin source show no evidences of it.

Acknowledgements - The authors thank Dr. Marcos Fernandez for the contributions all along the development of this study.

\section{REFERENCES}

AXIAK, V., VELLA, A. J., MICALLEF, D., CHIRCOP, P. \& MINTOFF, B., 1995, Imposex in Hexaplex trunculus (Gastropoda: Muricidae): frist results from biomonitoring of tributyltin contamination in the Mediterranean. Mar. Biol., 121: 685-691.

AXIAK, V., MICALLEF, D., MUSCAT, J., VELLA, A. J. \& MINTOFF, B., 2002, Imposex as a biomonitoring tool for marine pollution by tributyltin: some further observations. Environ. Int., 976: 1-7.

BECH, M., 2002, Imposex and tributyltin contamination as a consequence of the establishment of a marina, and increasing yachting activities at Phuket Island, Thailand. Environ. Pollut., 117: 421-429.

CAETANO, C. H. S. \& ABSALÃO, R. S., 2003, Imposex in Olivancillaria vesica vesica (Gmelin) (Gastropoda, Olividae) from a Southeastern Brazilian sandy beach. Sci. Total Environ., 19: 215-218.

CAMILlO, E., QUADROS, J., CASTRO, I. B. \& FERNANDEZ, M. A. S., 2004, Imposex in Thais rustica (Mollusca:Neogastropoda) (Lamarck, 1822 ) as an indicator of organotin compounds pollution at Maceió coast (Northeastern Brazil). Braz. J. Ocean., 52: 101-105.

CASTRO A. F., AMARO, V. E. \& VITAL, H., 2003, Desenvolvimento de um banco de dados geográficos em um ambiente SIG e sua aplicação na elaboração de mapas de sensibilidade ambiental ao derramamento de óleo em áreas costeiras do estado do Rio Grande do Norte. Anais XI SBSR, Belo Horizonte, Brasil, INPE, p. 1533-1540.

CASTRO, I. B., MATTHEWS-CASCON, H. \& FERNANDEZ, M. A. S., 2000, Imposex em Thais haemastoma (Linnaeus, 1767) (Mollusca: Gastropoda) uma indicação da contaminação por organoestânicos na costa do município de Fortaleza. Arq. Ciên. Mar., 33: 51-56.

CASTRO, I. B., MEIRELLES, C. A. O., MATTHEWS-CASCON, H. \& FERNANDEZ, M. A. S., 2004, Thais (Stramonita) rustica (Lamarck, 1822) (mollusca: Gastropoda: Thaididae), a potential bioindicator of contamination by organotin Northeast Brazil. Braz. J. Ocean., 52: 135139.

CASTRO, I. B., BEMVENUTI, C. E. \& FILLMANN, G., 2007, Preliminary appraisal of imposex in areas under the influence of Southern Brazilian harbors. J. Braz. Soc. Ecotox., 2: 73-79.

CASTRO, I. B., RODRIGUES, L. \& ROCHA-BARREIRA, C. A., 2007, Compostos orgânicos de estanho: efeitos sobre a fauna marinha - uma revisão. Arq. Cien. Mar, in press.

CEP, 2004, Ceará harbors, relatories on pecém harbor movements, http:// www.cearaportos.com.br/, accessed in April, 2004. (in Portuguese).
DAVIES, I. M., HARDING, M. J. C., BAILEY, S. K., SHANKS, A. M. \& LANGE, R., 1997, Subletal effects of tributyltin oxide on the dogwelk Nucella lapillus. Mar. Ecol. Progress Series, 158: 191-204.

FERNANDEZ, M. A. S., LIMAVERDE, A. C., CASTRO, I. B., WAGENER A. L. R. \& ALMEIDA, A. C. O., 2002, Occurence of imposex in Thais haemastoma: possible evidence of environmental contamination derived from organotin compounds in Rio de Janeiro and Fortaleza, Brazil. Rep. Pub. Health, 18: 463-476.

FERNANDEZ, M. A. S., WAGENER A. L. R., LIMAVERDE, A. C., SCOFIELD, A. L., PINHEIRO, F. M. \& RODRIGUES, E., 2005, Imposex and surface sediment speciation: a combined approach to evaluate organotin contamination in Guanabara Bay, Rio de Janeiro, Brazil. Mar. Environ. Res., 59: 435-452.

GIBBS, P. E. \& BRYAN, G. M., 1987, TBT paints and demise of the dogwhelk Nucella lapillus (Gastropoda). J. Mar. Biol. Assoc. U. K., 68: 14821487.

GOODING, M., GALLARDO, C. \& LEBLANC, G., 1999, Imposex in three marine Gastropod species in Chile and potential impact on Muriciculture. Mar. Pollut. Bull., 38: 1227-1231.

HORIGUCHI, T., SHIRAISHI, H., SHIMIZU, M. \& MORITA, M., 1997, Imposex in sea snails caused by organotin (tributyltin and triphenyltin) pollution in Japan: a survey. Appl. Organometallic Chem., 11: 451-455.

MAIA, L. P., 1998, Procesos costeros y balance sedimentario a lo largo de Fortaleza (NE-Brasil): Implicaciones para una gestón adecuada de la zona litoral. Tese de Doutorado, Programa de Doutorado em Ciências do Mar, Universitad de Barcelona, Barcelona, 269 p.

MATTHIESSEN, P. \& GIBBS, P. E., 1998, Critical appraisal of the evidence for tributyltin - mediated endocrine disruption in Mollusks. Environ. Toxicol. Chem., 17: 37-43.

MENSINK, B. P., BOON, J. P., TEM HALLERS-TJABBES, C. C., HATTUM, B. V. \& KOEMAN, J. H., 1997, Bioaccumulation of organotin compounds and imposex occurrence in a marine food chain (Eastern Scheldt, the Netherlands). Environ. Techn., 18: 1235-1244.

MINCHIN, A. \& MINCHIN, D., 1997, Dispersal of TBT from a fishing port determined using the dogwhelk Nucella lapillus as an indicator. Environ. Techn., 38: 1225-1234.

MINCHIN, D., STROBEN, E., OEHLMANN, J., BAUER, B., DUGGAN, C. B. \& KEATINGE, M., 1996, Biological indicators used to map organotin contamination in Cork Harbour, Ireland. Mar. Pollut. Bull., 32: 188195.

MINCHIN, D., 2003, Monitoring of tributyltin contamination in six marine inlets using biological indicators. Mar. Environ. Health Ser., 6: 1-15.

MTB, 2004, Ministério dos Transportes do Brasil, Relatories on Brazilian Harbors movement, http://www.transportes.gov.br/, accessed in: April of 2004. (in Portuguese)

MORCILLO, Y. \& PORTE, C., 1998, Monitoring of organotin compounds and their in marine molluscs. TRAC., 17: 109-116.

PENCHASZADEH, P. E., AVERBUJ, A. \& CLEDÓN, M., 2001, Imposex in gastropods from Argentina (southwestern Atlantic) Nucella lapillus and the common whelk Buccinum undatum as indicators of TBT contamination. Mar. Pollut. Bull., 42: 790-791.

TEM HALLERS-TJABBES, C. C., WAGERNER, J., HATTUM, B. V., KEMP, J. F., TEM HALLERS, E., REITSEMA, T. J. \& BOON, J. P., 2003, Imposex and organotin concentrations in Buccinum undatum and Neptunea antiqua from the North Sea: relationship to shipping density and hydrological conditions. Mar. Environ. Res., 55: 203-233. 